\title{
Jean Chaperon, Le Chemin de long estude de Dame Cristine de Pise (1549)
}

\section{Michele Mastroianni}

\section{Q OpenEdition}

1 Journals

\section{Édition électronique}

URL : http://journals.openedition.org/studifrancesi/7869

DOI : 10.4000/studifrancesi.7869

ISSN : 2421-5856

Éditeur

Rosenberg \& Sellier

\section{Édition imprimée}

Date de publication : 1 juillet 2009

Pagination : 380

ISSN : 0039-2944

\section{Référence électronique}

Michele Mastroianni, « Jean Chaperon, Le Chemin de long estude de Dame Cristine de Pise (1549)», Studi Francesi [En ligne], 158 (LIII | II) | 2009, mis en ligne le 30 novembre 2015, consulté le 13 janvier 2021. URL : http://journals.openedition.org/studifrancesi/7869; DOI : https://doi.org/10.4000/studifrancesi. 7869

Ce document a été généré automatiquement le 13 janvier 2021.

\section{(c)}

Studi Francesi è distribuita con Licenza Creative Commons Attribuzione - Non commerciale - Non opere derivate 4.0 Internazionale. 


\title{
Jean Chaperon, Le Chemin de long estude de Dame Cristine de Pise (1549)
}

\author{
Michele Mastroianni
}

\section{RÉFÉRENCE}

JEAN CHAPERON, Le Chemin de long estude de Dame Cristine de Pise (1549), introduction, édition critique et notes par Claire LE BRUN-GOUANVIC, Paris, Champion, 2008 («Textes de la Renaissance», 139), pp. 298.

1 Le Livre du Chemin de long estude, composto in versi da Christine de Pizan tra il 1402 e il 1403, è l'ultima opera di Christine ad essere ristampata nel Cinquecento (precisamente nel 1549 dall'imprimeur Étienne Groulleau a Parigi). Non si tratta, tuttavia, di una stampa pura e semplice, come per altre opere, bensì di una ritrascrizione in prosa ad opera di Jean Chaperon. Viene ora offerta l'edizione critica di questa mise en prose, estremamente interessante dal punto di vista linguistico (Jean Chaperon, che descrive la sua impresa come una traduzione «de langue Romanne en prose Françoyse», procede alla derimazione modernizzando la lingua), mise en prose che ancora degli eruditi del Settecento hanno considerato il testo originale di Christine. La presente edizione, sobriamente ma puntualmente annotata, è preceduta da un'ampia introduzione, una vera e propria monografia (pp. 11-117), che illustra il Chemin de long estude, ricostruisce la storia della fortuna di Christine nel Quattro e Cinquecento, repertoriandone le edizioni francesi tra la fine del XV secolo e la prima metà del XVI, e traccia un profilo storico di Jean Chaperon. Ma soprattutto offre allo storico della lingua una minuziosa analisi contrastiva del testo originale e della sua mise en prose, studiando accuratamente il lavoro del traduttore, in particolare i procedimenti - retorici - di riscrittura. 